\title{
DYNAMIC ANALYSIS OF OVERHEAD POWER LINES AFTER ICE-SHEDDING USING FINITE ELEMENT METHOD
}

\author{
Justín Murín * Juraj Hrabovský ${ }^{*}$ \\ Roman Gogola * František Janíček ${ }^{* *}$
}

\begin{abstract}
In this paper, the analysis of ice-shedding from ACSR conductors to its swing up height and vibration using Finite Element Method (FEM) is presented. For the numerical simulations the effective material properties of the ACSR conductor are calculated using the homogenisation method. Numerical analysis concerning vibration of one and triple-bundle conductors with icing for a whole range or on their certain parts are performed. The impact of ice-shedding to the mechanical tension in the conductors at the points of attachment is investigated and evaluated. Identification of the impact of ice-shedding from the ACSR conductors on its mechanical state may contribute to increasing the safety and quality of an electrical transmission system.
\end{abstract}

K e y w o r d s: overhead power lines, ice-shedding, finite element method, transient analysis

\section{INTRODUCTION}

In cold regions, atmospheric icing is one of the major external loads threatening the reliability and mechanical security of overhead power lines. Ice-shedding happens when the ice formed on conductors suddenly drops off (under natural conditions, such as temperature rise and wind action or man-made shocks) [1]. This will cause high-amplitude oscillations of the conductors and large transient forces on the insulators and towers [2]. Also this may lead to the flashover if the phase-to-phase or phase-to-tower distance is smaller than the tolerable insulation distance. To evaluate these potential electrical and mechanical problems, the maximum conductor jump heights and tensions need to be determined. Therefore, the transient analysis of ice-shedding is needed.

The ice-shedding is investigated with experimental, numerical and theoretical methods by many authors [3]. Very approximate practical models were suggested as early as the 1940s [4]. With the improvement of computational mechanics, numerical simulation methods (over all the FEM) were used to study ice-shedding from the power lines eg in [5-7] dynamic responses of transmission lines with different parameters, bundle conductors and five-span line section after ice-shedding is numerically simulated. In [8], a new theoretical method to calculate the jump height of the overhead power line after ice-shedding is presented.

In this paper, the results of transient analyses of iceshedding from the single and triple-bundle ACSR power lines are presented. The results are calculated using a commercial finite element software ANSYS

\section{HOMOGENIZATION OF MATERIAL PROPERTIES}

It is complicated to model the ACSR conductor with its real construction (eg inhomogeneous material properties), therefore a simplified model is used. The heterogeneous cross-section of several ACSR conductors are shown in Fig. 1. That is the reason why homogenized material properties have to be calculated [9-11].

At our department, the material homogenization methods were derived for functionally graded material (FGM) [10-12]. These homogenization techniques (with some modifications) can also be used for homogenization of the ACSR conductors. The effective elasticity moduli for axial, shear, flexural and torsional loading are calculated from condition, that the relevant stiffness of the conductor cross-section with real construction (Fig. 2) is equal to the stiffness of the homogenized cross-section.

The real cross-section parameters of ACSR conductor are: $R_{i}(\mathrm{~mm})$ is the pitch circle, $d_{i}(\mathrm{~mm})$ is the wire diameter, $\varphi_{i}\left(^{\circ}\right)$ is the angle of circumferential position of the wire, $z_{i}(\mathrm{~mm})$ and $y_{i}(\mathrm{~mm})$ are the distances of the wire from the centre of the conductor cross-section. These distances of each wire can be calculated as follows [13]

$$
\begin{aligned}
y_{i} & =R_{i} \sin \varphi_{i}, \\
z_{i} & =R_{i} \cos \varphi_{i} .
\end{aligned}
$$

Then the quadratic moment of the $i^{\text {th }}$ wire cross-sectional area $A_{i}=\pi d_{i}^{2} / 4$ according the axis $y$ and according the

Faculty of Electrical Engineering and Information Technology, Slovak University of Technology, Ilkovičova 3, 81219 Bratislava, Slovakia,

* Institute of Automotive Mechatronics, justin.murin@stuba.sk,juraj.hrabovsky@stuba.sk, roman.gogola@stuba.sk

** Institute of Power and Applied Electrical Engineering, frantisek.janicek@stuba.sk 


\section{.}
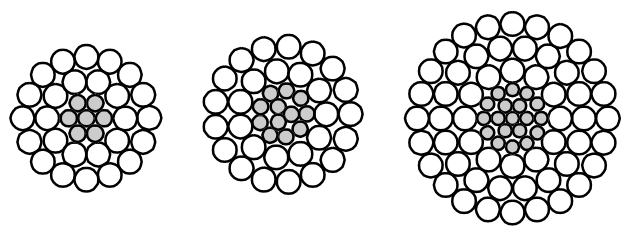

Fig. 1. Construction of ACSR conductors

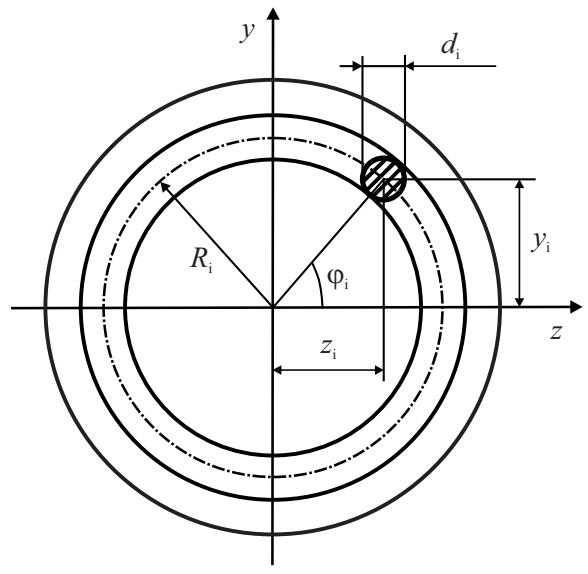

Fig. 2. Conductor cross-section

Table 1. Calculation of the reference icing load $I_{R}[14]$

\begin{tabular}{cc}
\hline Icing & Reference icing load $I_{R}\left(\mathrm{Nm}^{-1}\right)$ \\
\cline { 2 - 2 } area & $d \leq 30 \mathrm{~mm}$ \\
\hline N0 & $1.298+0.1562 d$ \\
N1 & $3.873+0.2698 d$ \\
N2 & $10.566+0.4457 d$ \\
N3 & $18.305+0.5866 d$ \\
N5 & $35.376+0.8155 d$ \\
N8 & $63.077+1.0890 d$ \\
N12 & $102.063+1.3852 d$ \\
N18 & $162.924+1.7501 d$ \\
NK & It is determined on a case by case \\
\hline
\end{tabular}

axis $z$ can be calculated by equations [13]

$$
\begin{aligned}
I_{y i} & =\frac{\pi d_{i}^{4}}{64}+z_{i}^{2} \frac{\pi d_{i}^{2}}{4}, \\
I_{z i} & =\frac{\pi d_{i}^{4}}{64}+y_{i}^{2} \frac{\pi d_{i}^{2}}{4} .
\end{aligned}
$$

The polar moment of the wire cross-sectional area to origin of the coordinate system $x, y$ is $[13]$

$$
I_{p i}=I_{y i}+I_{z i} .
$$

The maximal elasticity modulus for lateral and transversal bending can be calculated by equations $[13,14]$

$$
\begin{aligned}
& E_{L \text { max }}^{M_{y} H}=\frac{\sum_{i=1}^{n} E_{i} I_{y i}}{\sum_{i=1}^{n} I_{y i}}, \\
& E_{L \text { max }}^{M_{z} H}=\frac{\sum_{i=1}^{n} E_{i} I_{z i}}{\sum_{i=1}^{n} I_{z i}},
\end{aligned}
$$

The maximal elasticity modulus represents the case, when all the wires are fixed together (egafter several years of lifetime). The minimal elasticity modulus for lateral and transversal bending can be calculated by equations $[13,14]$

$$
\begin{aligned}
& E_{L \text { min }}^{M_{y} H}=\frac{\frac{\pi}{64}\left[n_{\mathrm{Fe}} d_{\mathrm{Fe}}^{4} E_{\mathrm{Fe}}+n_{\mathrm{Al}} d_{\mathrm{Al}}^{4} E_{\mathrm{Al}}\right]}{\sum_{i=1}^{n} I_{y i}}, \\
& E_{L \text { min }}^{M_{z} H}=\frac{\frac{\pi}{64}\left[n_{\mathrm{Fe}} d_{\mathrm{Fe}}^{4} E_{\mathrm{Fe}}+n_{\mathrm{Al}} d_{\mathrm{Al}}^{4} E_{\mathrm{Al}}\right]}{\sum_{i=1}^{n} I_{z i}}
\end{aligned}
$$

where $n_{\mathrm{Fe}}$ is the number of steel wires and $n_{\mathrm{Al}}$ is the number of aluminium wires. The minimal elasticity modulus represents the case, when wires can slide over each other. In practice the effective elasticity modulus for lateral and transversal bending is assumed as average value of maximal and minimal elasticity moduli [14]

$$
\begin{aligned}
& E_{L}^{M_{y} H}=\frac{E_{L \text { max }}^{M_{y} H}+E_{L \text { min }}^{M_{y} H}}{2}, \\
& E_{L}^{M_{z} H}=\frac{E_{L \text { max }}^{M_{z} H}+E_{L \text { min }}^{M_{z} H}}{2} .
\end{aligned}
$$

We assume also, that the effective Poisson's ratio is equal to [13]

$$
\nu_{L}^{N H}=\frac{\sum_{i=1}^{n} \nu_{i} A_{i}}{\sum_{i=1}^{n} A_{i}}
$$

where $\nu_{i}$ is the Poisson's ratio of $i^{\text {th }}$ wire. The effective mass density for axial beam vibration is [13]

$$
\rho_{L}^{N H}=\frac{\sum_{i=1}^{n} \rho_{i} A_{i} k_{i}}{A}
$$

Where $\rho_{i}\left(\mathrm{~kg} \mathrm{~m}^{-3}\right)$ is the material density of each wire and $k_{i}(\%)$ is the each material weight increment due to stranding.

\section{ICING AND ICE SHEDDING FROM POWER LINES}

Accumulating of ice on overhead conductors is a very frequently problem for transmission systems situated in cold regions. Icing can also cause mechanical damage of the power line systems because the tension in conductors can increase to the limits.

In practice, the designers of power line transmission systems calculate the tension in conductors using a state equation [15] into which the design icing loads for the area to which the designed power transmission system is proposed (Tab. 1) has to be included. At first, the reference icing load $I_{R}\left(\mathrm{Nm}^{-1}\right)$ to unit length of the conductor with the diameter $d(\mathrm{~mm})$ is calculated using the equation shown in Tab. 1. 


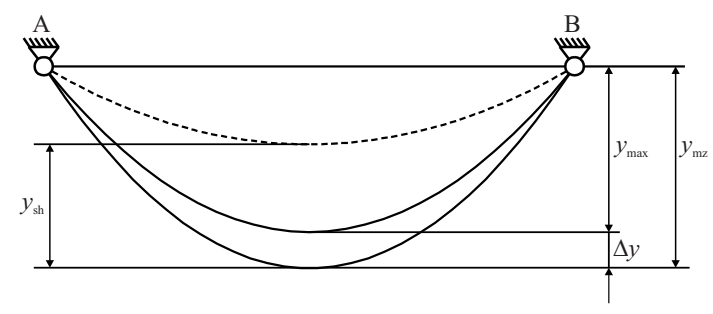

Fig. 3. Ice-shedding from power line [14]

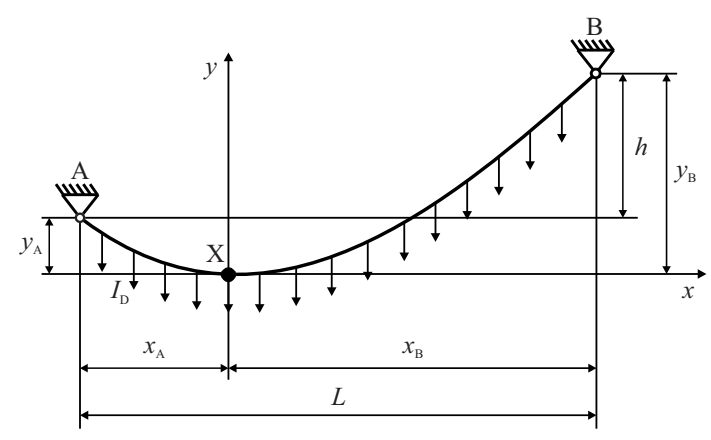

Fig. 4. Transient analysis model with icing [20]

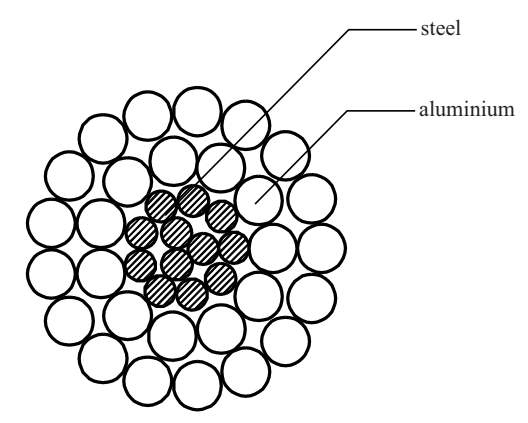

Fig. 5. Cross-section of the considered ACSR conductor

The nominal design icing load $I_{D}$ is calculated using the formula [14]

$$
I_{D}=K_{h} I_{R} \gamma_{I}
$$

where $K_{h}$ is the height factor of the icing load, $\gamma_{I}$ is the partial icing load factor [14]. In the calculations of the mechanical stresses the weather load factor $z$ (include icing) is needed which is calculated using equation [14]

$$
z=\frac{q_{1}+I_{D}}{q_{1}}
$$

where $q_{1}\left(\mathrm{Nm}^{-1}\right)$ is the gravity load of conductor [14]. In Slovakia in practice calculations, the main used icing area is $\mathrm{N} 2$, so in simulations of ice-shedding the icing load is calculated for this case.

When the ice formed on the conductor drops off under weather conditions (temperature, wind) or man-made shocks it can cause ice-shedding [1,14] (Fig. 3).

The ice-shedding can cause vibrations with high amplitudes and high forces in conductors (high forces at points of attachment). That is the reason why the maximal conductor jump and tensions are needed to determine. The analytical solution is available only for simple (symmetric) models $[14,16]$. For evaluation of these problems the numerical simulations using the nonlinear analyses are needed.

Ice-shedding is a nonlinear dynamic process, so an implicit method with Newmark time integration scheme is used. Equilibrium equations with the time steps $t+\Delta t$ are in the following form [17-19],

$$
\underline{M} \underline{\ddot{U}}^{t+\Delta t}+\underline{C} \underline{\dot{U}}^{t+\Delta t}+\underline{K} \underline{U}^{t+\Delta t}=\underline{F}^{t+\Delta t}
$$

where $\underline{M}, \underline{C}$ and $\underline{K}$ is the mass matrix, the damping matrix and the stiffness matrix, respectively. Again, $\underline{\ddot{U}}$ is the acceleration, $\underline{\dot{U}}$ is the velocity, $\underline{U}$ is the displacement vector and $\underline{F}$ is the external loads vector. The damping of mechanical systems can be described using Rayleigh's formulae of material damping. The damping matrix is calculated from the equation

$$
\underline{C}=\alpha \underline{M}+\beta \underline{K}
$$

where $\alpha$ and $\beta$ are constants, and they are calculated from the damping ratio [17-19].

\section{NUMERICAL EXPERIMENTS}

Transient analyses of the single and triple-bundle conductors according to Fig. 4 have been considered.

The length of the span is $L=300 \mathrm{~m}$ and the height difference between the points of attachment is $h=10 \mathrm{~m}$. The maximal deflection of the power line $[14,16]$ is $y_{A}=$ $3.557 \mathrm{~m}$ and the axial force is $N_{B}=25.975 \mathrm{kN}$ (for simplicity, a constant maximal value for the whole line length was assumed).

The modelled symmetric conductor ACSR 445/74 [21] which is constructed from $3+9$ steel and $11+17$ aluminum wires (see Fig. 5) has been considered. The diameter of the aluminum wires is $d_{\mathrm{Al}}=4.5 \mathrm{~mm}$ and the diameter of the steel wires is $d_{\mathrm{Fe}}=2.8 \mathrm{~mm}$. The effective crosssections of the conductor parts are: $A_{\mathrm{Fe}}=73.89 \mathrm{~mm}^{2}$, $A_{\mathrm{Al}}=445.32 \mathrm{~mm}^{2}$ and the effective cross-sectional area of the power line is $A=519.21 \mathrm{~mm}^{2}$.

Material properties of the used materials are $[22,23]$ : aluminum - the elasticity modulus $E_{\mathrm{Al}}=69000 \mathrm{MPa}$, the Poisson's ratio, $\nu_{\mathrm{Al}}=0.33$, the mass density $\rho_{\mathrm{Al}}=$ $2703 \mathrm{kgm}^{-3}$; steel — the elasticity modulus $E_{\mathrm{Fe}}=$ $207000 \mathrm{MPa}$, the Poisson's ratio $\nu_{\mathrm{Fe}}=0.28$, the mass density $\rho_{\mathrm{Fe}}=7780 \mathrm{kgm}^{-3}$. Material properties for spacer dampers are: Young's modulus $E_{\mathrm{SD}}=75000 \mathrm{MPa}$, Poisson's ratio $\nu_{\mathrm{SD}}=0.33$, material density $\rho_{\mathrm{SD}}=$ $2730 \mathrm{kgm}^{-3}$.

The effective quadratic area moments of the conductor cross-sectional area are: $I_{z}=I_{y}=28528.3 \mathrm{~mm}^{4}$. The effective circular cross-section of conductor is constant with diameter $d_{\mathrm{ef}}=25.71 \mathrm{~mm}$ and the deformed length of the conductor is $L_{\mathrm{d}}=301.20 \mathrm{~m}$. The nominal design icing load is $I_{D}=23.83 \mathrm{Nm}^{-1}$ for the N2 icing area [14]. 


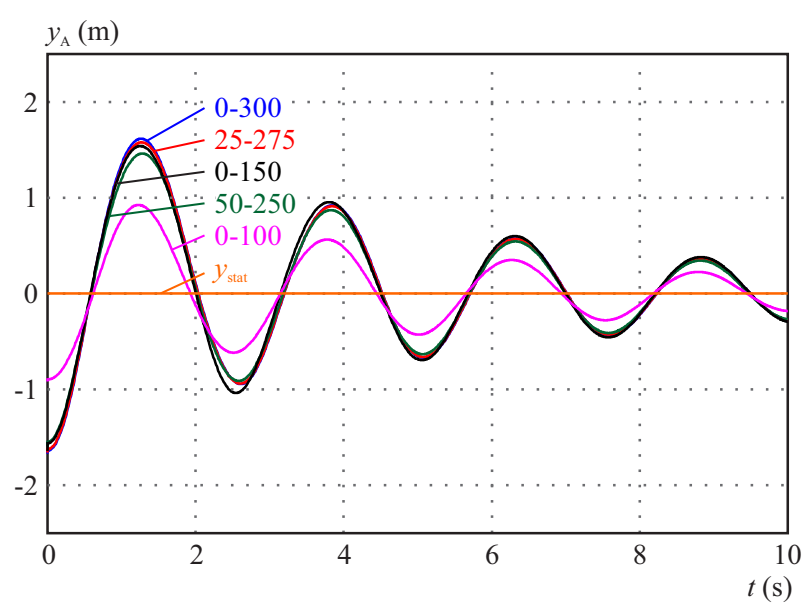

Fig. 6. Time dependency of single power line vibration after iceshedding for different icing location, [20], at point $\mathrm{X}$ in Fig. 4

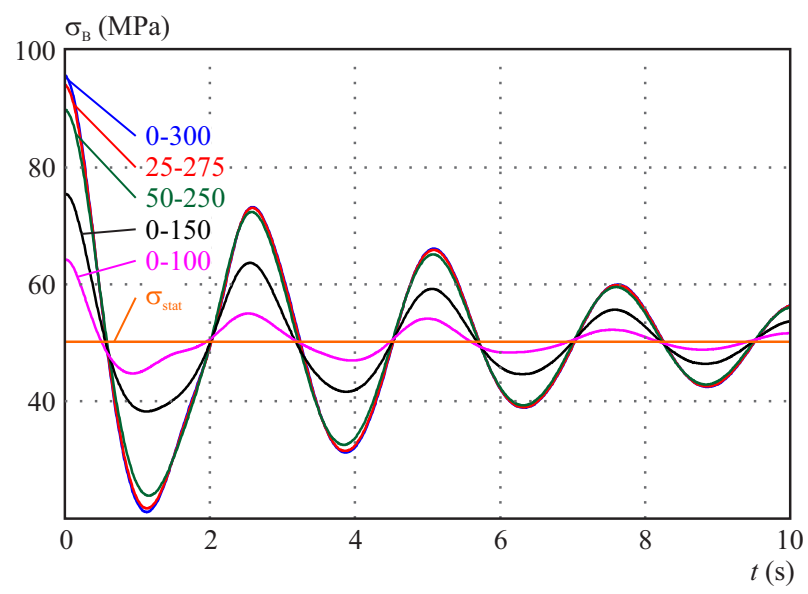

Fig. 8. Time dependency of mechanical stresses after ice-shedding at the point of attachment (point B) for triple-bundle conductor [20] for different icing location

The effective material properties of the used conductor are

$$
\begin{aligned}
& E_{L}^{M_{y} H}=E_{L}^{M_{z} H}=47929.78 \mathrm{MPa} \\
& \nu_{L}^{N H}=0.323 \\
& \rho_{L}^{N H}=3482.81 \mathrm{kgm}^{-3} .
\end{aligned}
$$

These calculated effective material properties have been used in the transient analysis of the single and triplebundle overhead power lines. Transient analyses of the ice-shedding of the single conductor have been done with a mesh 1200 of BEAM188 elements of the FEM program ANSYS [19]. For triple-bundle conductor with spacer dampers the analysis of ice-shedding have been done with a mesh 3645 of BEAM188 elements. Triple-bundle conductors are connected with five spacer dampers distributed along the line in 50 meters distance.

As expected, with icing on power lines the axial force in conductors and the deflection increases. Tab. 2 summarizes the maximal axial forces in the single and triple-

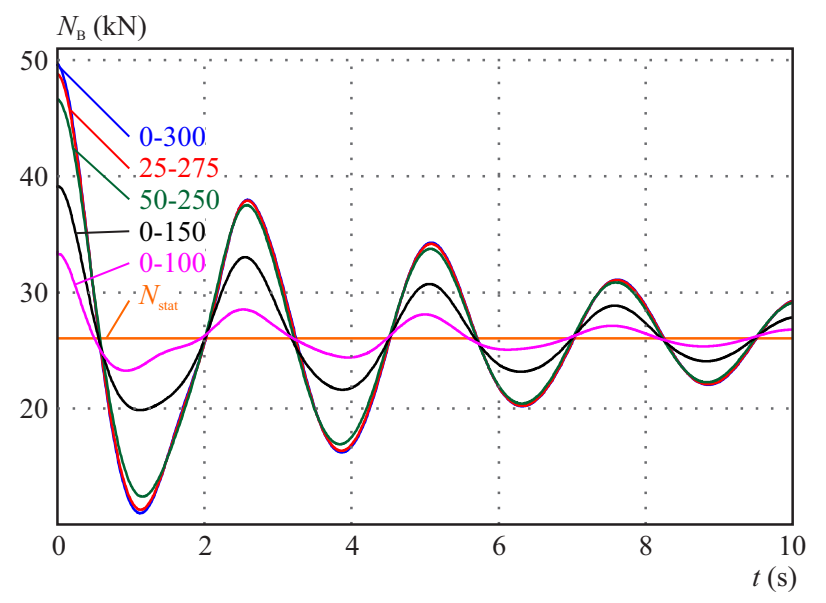

Fig. 7. Time dependency of axial forces after ice-shedding at the point of attachment (point B in Fig. 3) for triple-bundle conductor, [20] for different icing location

bundle conductors with icing, the changes of the deflection of the single and triple-bundle conductors, respectively.

As we can see in Tab. 2, there are small differences between the results of axial forces and changes in deflection in single and triple-bundle power lines. The differences are caused by spacer dampers placed on the conductors.

After the ice-shedding the conductor swings up and the jump heights $y_{\mathrm{sh}}(\mathrm{m})$ are different for every range of the icing on the conductors in span. The results of swing up heights of single and triple-bundle conductors with the maximal swing up times are shown in Tab. 3. In the case of asymmetrical position of icing (0-150 $\mathrm{m}$ and $0-100 \mathrm{~m})$ the place of maximal deflection is observed (point $\mathrm{X}$ in Fig. 4).

As shown in Tab. 3, there small differences between the results of swing up height and the time of maximal swing up for single and triple-bundle conductors occur. The differences are caused by a different geometry and stiffness of the whole system.

After the ice-shedding the conductor will perform oscillating motion. This dynamic phenomenon is damped by the own damping of the power line and the damping of the environment. The used constants $\alpha\left(\mathrm{s}^{-1}\right)$ and $\beta(\mathrm{s})$ for the Rayleigh's damping are calculated from the damping ratio used in [17-19]. Time dependency of the single power line move after the ice-shedding for different range of ice-shedding is shown in Fig. 6. Time dependency of axial forces and mechanical stresses at the point of attachment (point B) for triple-bundle conductors are shown in Figs. 7 and 8. The distribution of the axial forces in overhead triple-bundle conductor after the first bounce for the case of ice-shedding $25-275 \mathrm{~m}$ is shown in Fig. 9. The maximum is marked by the red color and symbol MX.

\section{CONCLUSIONS}

In this paper the FEM analysis of ice-shedding on overhead power lines (single and triple-bundle) is pre- 


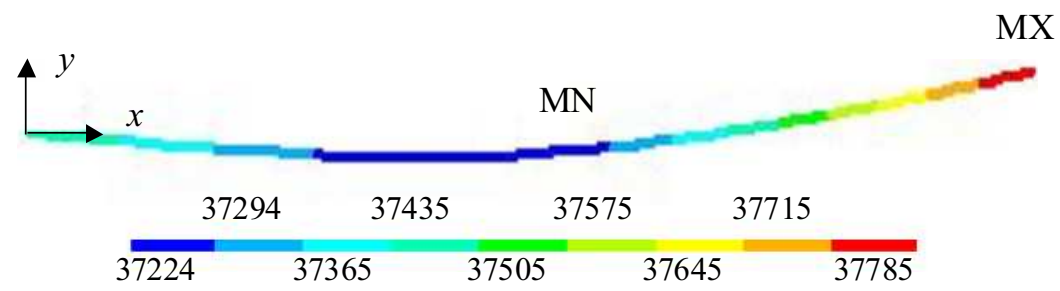

Fig. 9. The axial forces in $\mathrm{N}$ at overhead triple-bundle conductor after the first bounce for the case of ice-shedding $25-275 \mathrm{~m}$

Table 2. Maximal axial forces at the higher attachment point on insulator (point $\mathrm{B}$ ) and the change in deflection $\Delta y$ (compared to the state with no icing) at the lowest point (point $\mathrm{X}$ ), depending on the icing location [20]

\begin{tabular}{ccccc}
\hline \multirow{2}{*}{ Icing location $(\mathrm{m})$} & \multicolumn{2}{c}{ single } & \multicolumn{2}{c}{ triple-bundle } \\
& ACSR conductor & \multicolumn{2}{c}{ ACSR conductor } \\
\cline { 2 - 5 } & $N_{B}(\mathrm{~N})$ & $\Delta y(\mathrm{~m})$ & $N_{B}(\mathrm{~N})$ & $\Delta y(\mathrm{~m})$ \\
\hline without icing & 25975.7 & - & 26060.3 & - \\
$0-300$ & 49383.2 & 1.640 & 49630.1 & 1.630 \\
$25-275$ & 48521.7 & 1.626 & 48782.2 & 1.615 \\
$50-250$ & 46264.3 & 1.547 & 46576.8 & 1.535 \\
$0-150$ & 38873.7 & 1.562 & 39102.2 & 1.564 \\
$0-100$ & 33117.8 & 0.897 & 33284.8 & 0.943 \\
\hline
\end{tabular}

Table 3. Maximal height of swing up at time for single and triplebundle power line [20]

\begin{tabular}{ccccc}
\hline \multirow{2}{*}{ Icing location $(\mathrm{m})$} & \multicolumn{2}{c}{ single } & \multicolumn{2}{c}{ triple-bundle } \\
& power line & \multicolumn{2}{c}{ power line } \\
& $y_{\mathrm{sh}}(\mathrm{m})$ & $t(\mathrm{~s})$ & $y_{\mathrm{sh}}(\mathrm{m})$ & $t(\mathrm{~s})$ \\
\hline $0-300$ & 3.26 & 1.261 & 3.23 & 1.256 \\
$25-275$ & 3.20 & 1.266 & 3.18 & 1.261 \\
$50-250$ & 3.01 & 1.281 & 2.98 & 1.276 \\
$0-150$ & 3.10 & 1.251 & 3.11 & 1.251 \\
$0-100$ & 1.82 & 1.226 & 1.88 & 1.221 \\
\hline
\end{tabular}

sented. The unsymmetric span (different height of the points of attachment) of the symmetric conductor marked as ACSR $445 / 74-3+9$ steel and $11+17$ aluminum wires has been considered.

From the evaluation of all simulations of the conductor swing up after ice-shedding the following conclusions can be deduced:

The position of the icing on the power line has an significant impact to the swing up height, time of the maximal swing up.

The axial forces in the power lines increases very much when there is an icing in the whole range of the span. The position of the icing has an significant impact to the sag of the power line too.

In the case of triple-bundle power line, the upper conductors are highly stressed due to the applied spacer dampers, which represents concentrated forces to the points of attachment.
If the height difference between the points of attachment will be greater and on the power line will be icing, then the maximal axial forces in the upper point of attachment (on insulators) will be much more larger, but with correct dimensioning it will not have a negative impact on the safety of the transmission system.

\section{Acknowledgement}

This work was supported by the Slovak Research and Development Agency under the contract No. APVV0246-12, APVV-14-0613, APVV-15-0326 and by Grant Agency VEGA, grant No. 1/0228/14 and 1/0453/15.

Authors are also grateful to the HPC Center at the Slovak University of Technology in Bratislava, which is a part of the Slovak Infrastructure of High Performance Computing (SIVVP project, ITMS code 26230120002, funded by the European Regional Development Funds), for the computational time and resources made available.

\section{REFERENCES}

[1] JANÍČEK, F.-MURÍN, J.-LELÁK, J. : Load Conditions and Evaluation of the Rise of Temperature in an Enclosed Conductor, Journal of Electrical Engineering, 52 No. 07-08 (2001), 210-215.

[2] PIHERA, J.-MARTÍNEK, P.-KLASNA, J.-PASLAVSKÝ, B.-POLANSKÝ, R.-MENTLÍK, V.-TRNKA, P. : 2009 Annual Report Conference on Electrical Insulation and Dielectric Phenomena, CEIDP, Virginia Beach, VA; United States, pp. 39-42, Article number 5377890.

[3] POLANSKÝ, R.-PROSR, P.-MENTLÍK, V. et al : Thermal and Voltage Treatments of Silicone/Mica High-Temperature Electrical Insulation, Przegląd Elektrotechniczny $\mathbf{8 8}$ No. 8, (2012), 249-254.

[4] WU, C.-YANA, B.-ZHANG, L.-ZHANG, B.-LI, Q. : A Method to Calculate Jump Height of Iced Transmission Lines after Ice-Shedding, Cold Regions Science and Technology 125 (2016), 40-47.

[5] MORGAN, V. T.-SWIFT, D. A.: Jump Height of Overhead-Line Conductors after the Sudden Release of ice Loads, Proc. Inst. Electr. Eng. 111 (1964), 1736-1746.

[6] ROSHAN, F. M.-MCCLURE, G.: Numerical Modelling of the Dynamic Response of Ice-Shedding on Electric Transmission Lines, Atmos. Res. 46 (1998), 1-11.

[7] KOLLÁR, L. E.-FARZANEH, M. : Vibration of Bundled Conductors Following Ice Shedding, IEEE Trans. Power Delivery 23 No. 2 (2008), 1097-1104.

[8] KOLLÁR, L. E.-FARZANEH, M.-VANDYKE, P.: Modeling Ice Shedding Propagation on Transmission Lines with or 
without Interphase Spacersjour IEEE Trans. Power. Apparatus Syst..

[9] MURÍN, J.-KUTIŠ, V.: Improved Mixture Rules for the Composite (FGM's) Sandwich Beam Finite Element, Barcelona, Spain, 2007, pp. 647-650.

[10] KUTIŠ, V.-MURÍN, J.-BELÁK, R.-PAULECH, J. : Beam Element with Spatial Variation of Material Properties for Multiphysics Analysis of Functionally Graded Materials, Computers and Structures 89, 1192-1205.

[11] HRABOVSKÝ, J. : Multiscale Modelling and Simulation of Free Vibration of FGM Beams, Dissertation work, Bratislava.

[12] MURÍN, J.-HRABOVSKÝ, J.-PAULECH, J.-KUTIŠ, V.JANÍČEK, F.: Modelling of the Free Vibration of the Micro-Electro-Mechanical Systems, In Magnetic Measurements 2012: Programme and Book of Abstracts. International Conference, Bratislava: FEI STU, Tatranské Matliare, Slovakia, 2-4 September, 2012, 2012.

[13] MURÍN, J.-HRABOVSKÝ, J.-GOGOLA, R.-GÁLIK, G. : Modal Analysis of the Power Lines by Finite Element Methods, rev. EE časopis pre elektrotechniku, elektroenergetiku, informačné a komunikačné technológie (2014), Trenčín.

[14] FECKO, Š.-REVÁKOVÁ, D.-VARGA, L.-LAGO, J.ILENIN, S.: Vonkajšie elektrické vedenia, Renesans, s.r.o., Bratislava, 2010.

[15] BINDZÁR, M. : Stavová rovnica - výpočet montážnych tabuliek, Bratislava, 2015.

[16] FECKO, Š. et al : Elektrické siete: Vonkajšie silové vedenia, STU v Bratislave, Bratislava, 1990.

[17] MURÍN, J.-HRABOVSKÝ, J.-KUTIŠ, V.: Metóda Konečných prvkov - Vybrané kapitoly pre mechatronikov, STU v Bratislave - Nakladatestvo STU, Bratislava, 2014.

[18] KORTIŠ, J. : Numerické a experimentáne modelovanie účinkov pohyblivého zat'aženia na doskové kol'ajové podklady, Žilina, 2011.

[19] ANSYS Swanson Analysis System, Inc., 201 Johnson Road, Houston, PA 15342/1300, USA.

[20] GOGOLA, R.-HRABOVSKÝ, J.-MURÍN, J.-JANÍČEK, F. : FEM Analysis of Ice-Shedding on Overhead Power Lines, In Power engineering 2016. Energy-Ecology-Economy 2016: 13th International scientific conference, Tatranské Matliare, Slovakia, May 31 - June 2, 2016, Slovak University of Technology, Bratislava, 2016, pp. 126-131.

[21] STN EN 50182, Vodiče na vonkajšie vedenia. Vodiče koncentricky zlanovaných kruhových drôtov, 2001.

[22] STN EN 60889, Tvrdo t'ahané hliníkové drôty pre vodiče nadzemných elektrických vedení, 2001.

[23] ČSN EN 50189, Pozinkované ocelové drty pro vodiče venkovních vedení, 2000 .

Received 11 July 2016
Justín Murín (Prof, Ing, DrSc) was born in Oravská Lesná in 1951. He graduated from the Slovak University of Technology, Faculty of Mechanical Engineering, in 1975. He received PhD degree and DrSc degree in Applied mechanics in 1979 and 1994, respectively. In 1987 and 2001 he was appointed Associate Professor and Full Professor in Applied Mechanics. His teaching and research activities include analytical and numerical methods in mechanics and electro-thermomechanics, power engineering and mechatronics. Since 1985 he is employed at the Faculty of Electrical Engineering and Information Technology STU. From 1994 to 1998 he was employed at the TU Vienna. At present he is the head of the Department of Applied Mechanics and Mechatronics at the FEI STU of the Institute of Automotive mechatronics of FEI STU. He is cochairman of the Main Board in the Slovak Society for Mechanics. He is also the chair of Slovak branch of the Central European Association for Computational Mechanics (CEACM). Results of his scientific work are published in more as 250 papers and contributions.

Juraj Hrabovský (Ing, PhD) graduated from Slovak University of Technology, Faculty of Civil Engineering, in 2010 from Mathematical and Computational Modeling. He received $\mathrm{PhD}$ degree in Applied mechanics in 2013. His teaching and research activities include analytical and numerical methods in mechanics and electro- thermo-mechanics

Roman Gogola (Ing) graduated from Slovak University of Technology, Faculty of Electrical Engineering and Information Technology in 2013 from Applied Mechatronics. He is now $\mathrm{PhD}$ student of this faculty. His research activities include numerical methods in power engineering.

František Janíček (Prof, Ing, PhD) was born in Čadca in 1954. After finishing his doctoral studies he worked as an assistant lecturer till 1989, then as an associate professor till 1999 and from 1999 till now as full professor. He held the Office of the Dean of the Faculty of Electrical Engineering and Information Technology of STU in Bratislava from 1 February 2000 till 31 January 2007 and has been the Vice-Rector for Development of the Slovak University of Technology since 1 February 2007. He is a leading expert in the area of power engineering. He is one of the co-founders of the internet-based information and education project INFELEN (information on power engineering), the founder of the EE journal where he also acts as a member of the editorial board. He is a member of the Slovak WEC SR committee, a statutory representative of the EE Association (8 organizations) and a member of scientific boards of several universities in the SR. He supervises projects of national and international scientific research agencies in the field of renewable energy sources and power engineering. 